\title{
هوية الذبيه بين التوراة والانجيل والقران
}

م.د. ستنار جبار كاظم الدراجي

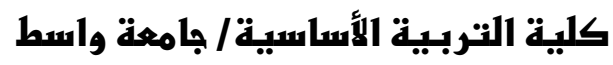

الإقدمة :

اتفقت الديانات السماوية على أن نبي الله إبراهيم (عليه السلام) هو عرافي المولد ، عربي الأصل ، فقد

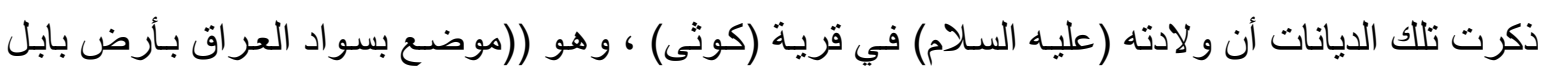

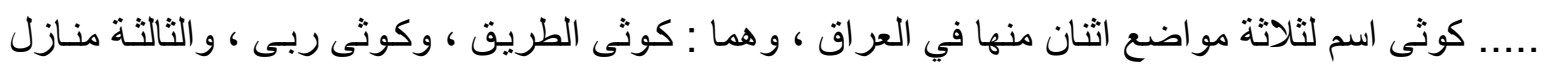

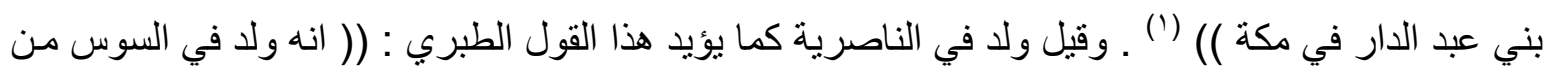

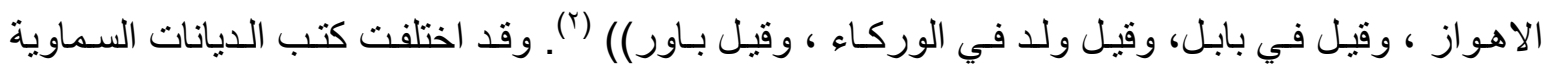

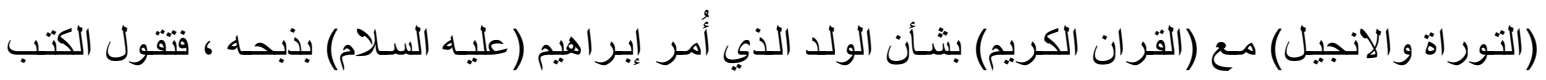

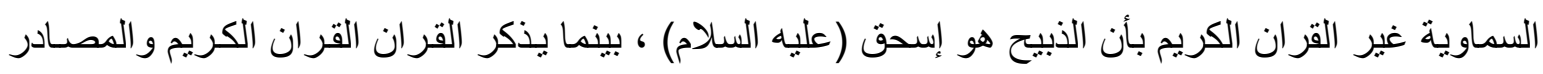
العربية بأن ذبيح الله إنما هو إسماعيل (عليه السلام) ـ وحاول اليهود و النصارى في هذه القضية على اعتبار ان الذبيح هو اسحق ، في واقع الامر يتعلق بنظرة أهل الكتاب حول (اختيار الثـعب الموعود) ، وهم بذللك

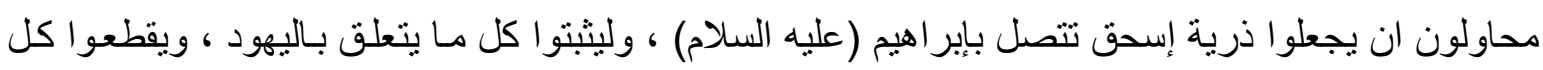

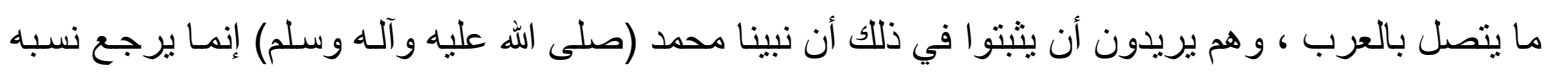
إلى إسحق.

و هنا يحاول البحث إثبات أن الذبيح هو نبي الله إسماعيل بن سيدنا إبراهيم (عليهما السلام) ، وهو الابن الأكبر له، وبذللك يكون نسب نبينا محمد (صلى الله عليه و آله وسلم) يرجع إلى إسـاعيل (عليه السلام) لا إلى هلى

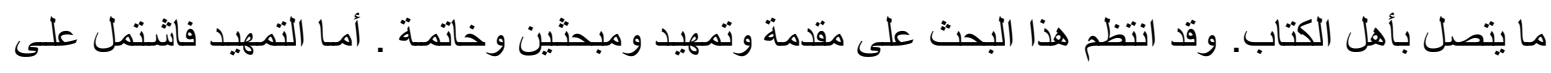
تعريفات لغوية واصطلاحية لمفردات العنوان ، وجاء المبحث الأول بعنوان : حياة إبر اهيم (عليه السـلام) في هي منظور الكتب السماوية، وفيه ثلاثة مطالب : المطلب الأول : حياة إبر اهيم (عليه السلام) في التوراة . و المطلب الثاني : حياة إبر اهيم (عليه السلام) في الإنجيل . و المطلب الثالث : حياة إبر اهيم (عليه السلام) في القران الكريم . أما المبحث الثاني، فكان بعنوان : (إثبات هوية الذبيح في الكتب السماوية) ، وفيه ثلاثة مطالب :

$$
\text { المطلب الأول : رؤيا إبراهيم (عليه السلام) في الذبيح . }
$$

و المطلب الثاني : إثبات هوية الذبيح من التور اة و الإنجيل . و المطلب الثالث : إثبات هوية الذبيح من القران الكريم . واحتوت الخاتمة على أهم النتائج التي توصل إليها البحث. التمهيد : الإطار العام للعنوان : 


\section{أولا / معنى الهوية لغةُ واصطلامًا :}

لفظ الهوية مصطلح حديث ظهر للوجود من خـلال الحياة السياسية والثقافية ، واختلف الباحثون في مفهوم الهويـة عبر مر احلـه التاريخيـة ، ويستند تعريف الهويـة الى مرجعيات متعددة ، لاسيما بعد ان اقتحم المفهوم جميع مجالات العلوم الانسانية ، ويمكن ان نرجع الاصل اللغوي للهوية والاصطلاحي الى : 1 ـ الهوية لغة : ((أصلها من هواء و الهواء الجو بين السماء والارض ،

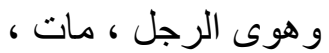
وهاوية والهاوية : تسم من أسماء جهنم ، و الهاوية : كل مهواة لا يدرك قعر ها ، و الهو اهي : الباطل و اللغو من القول ، و الهو هاءة ، بالمد : الأحمق ، والهوة : كل وهوة عميقة ، وهوية : تصغير هُوة ، وقيل الهوية : بئر بعيدة المهواة () (־)

وحد الهوية عند ابن حزم الظـاهري : ((هو كل مـا لم يكن غير الثـيء فهو هو بعينها ، إذ ليس بين

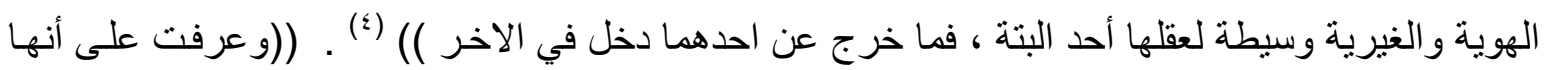
الحقيقة المطلقة ، المشتملة على الحقائق اشتمال النواة على الثـجرة في الغيب المطلق ، و الهويـة السـارية في جميع الموجودات : ما اذا اخذ حقيقة الوجود لا بشرط شيء ولا بشرط لا شيء )( (०) . نجد ان للمعنى اللغوي تعريفات متعددة لدرجة ان الناظر فيها بلاحظ فوضى تعريفية ، واختار البحث ابسط ما يكون معنى للهوية وهو : كل ما لم يكن غير الثيء فهو بعينه ، أبي أن غير الثشيء هو إقرار بهويـة الثيء الغيري ، أو بمعنى آخر ، الثيء ذاته والإقرار به ، و هذا التعريف هو المشترك الاكبر بين التعريفات اللغوية المتنو عة للهوية ، بحدود ما اطلعنا عليه في معنى الهوية . r - الهوية اصطلاحًا: أما اصطلاحا ((فان الهوية هي السمة الجو هرية العامة لثقافة من الثقافات ، لكن هذه السمة ليست ثابتة او جاهزة او نهائية ، كما يفهيها او يعرفها البعض احيانا ، ولذلك لا يمكننا صياغة تعريف إجر ائي لها و لا توصيفها وتحديد خصـائص ذاتيـة لها ، لأنها مشروع ثقافي مفتوح على المستقبل ، ولكنـه

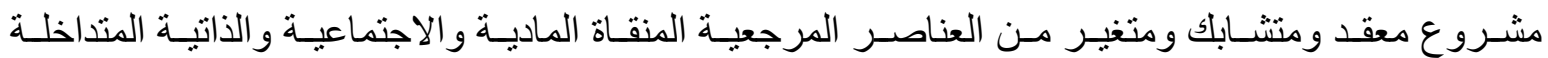

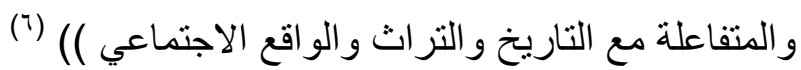

\section{ثانيا : تعريف الذبح لغةُ واصطلاهًاً}

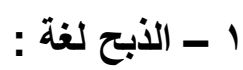

الذبح: قطع الحلقوم من باطن عند النصيل ، وموضعه المذبح ، و الذبيحة : الثناة المذبوحة ، 
و الذبح : ما أعد للذبح و هو بمنزلة الذبيح و المذبوح ،

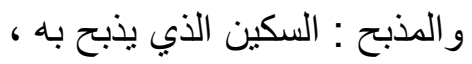

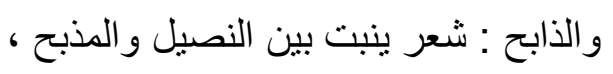

و الذبحة : داء يأخذ في الحلق وربما قتل ،

و الذبح: نبات له أصل يقتر عنه قشر اسود فيخرج ابيض كأنه جزرة ، حلو (طيب) يؤكل ، والواحدة

ذبحة ، ويقال: أخذه الذباح ، وهو تقتشف بين أصسابع الصبيان من التراب ، و الذابح: كوكب يقال لـه : سعد

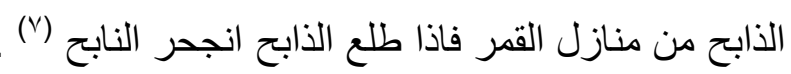

r ـ الذبح اصطلاحًا: ((هو قطع الأعضاء الأربعة ، المريء : وهو مجرى الطعام ، والحلقوم : وهو مجرى

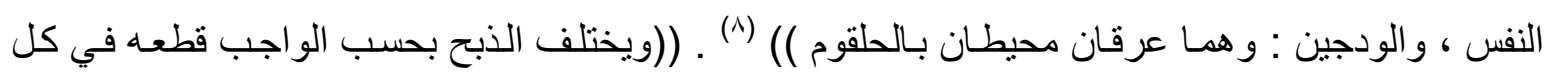

مذهب () (9)

\section{ثالثا : تعريف التوراة لغة واصطhالاما :}

1 ـ التوراة لغة : التوراة ((اسم عبر اني، وقد تكلف النحاة في اشتقاقها وفي وزنها ، وذلك بعد تقرير النحاة

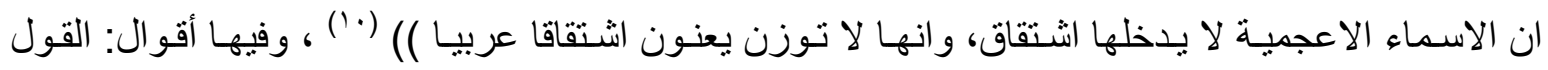
الأول: للفراء في اشتقاق التور اة: ((يجعلها من ورى الزند يري اذا خرجت نـاره ، و التور اة معناهـا الضياء الأول، من قول العرب: قد وريت بك زنادي ، قال: واصل التور اة: توريـة، على وزن تفعلة ، فصسارت الياء

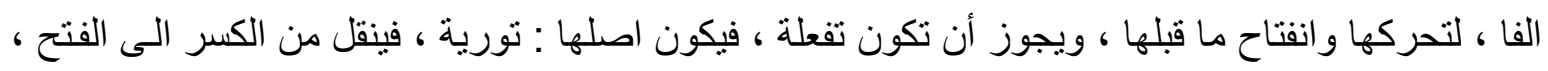

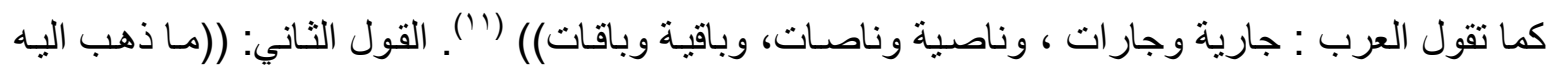
الخليل وسييويه ، وسـائر البصريين الى ان وزنها : فوعلة ، والتاء بـل من الواو ، كمـا ابدلت في نولج ، فالأصل فيها ووزنه وولج ، لأنها من ورى ، ومن ولج ، فهي كحوقلة ، وذهب الفراء الى ان وزنها تفعلة ،

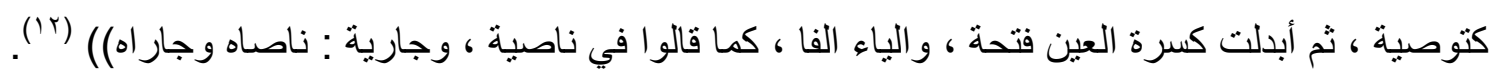
r - التوراة اصطلاحًا: ((كلمة عبارنية تعني الهداية والارشاد ، ويقصد بها الأسفار الخمسة الأولى [التكوين ن و الخروج ، و اللاويين ، و العدد ، و التثنية] و التي تتسب الى موسى [عليه السـلام ] ، و هي جزء من العهد

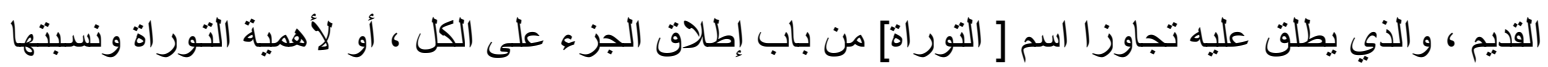
الى موسى ، و التور اة ، او العهد القديم ـ تميز الها عن العهد الجديد [كتاب المسيحيين المقد] - وهو كتاب اليهود الذي يضم الى جانب تاريخهم عقائدهم وشر ائعهم ، ويقسمه احبار اليهود الى ثلاثة أقسام : الناموس ، و الأنبياء ، و الكتابـات)) ("') ـ نجد ان معنى التور اة من خلال التعريف الاصطلاحي هي مجموعة الأوامر و الوصايا فضلا عن التشريعات والقوانين التي انزلها الله سبحانه وتعالى على نبيه موسى عليه السلام الى بين اسر ائيل في طور سيناء، التي اوصاهم بها اقامة كل ما فيها لأنها تتضمن ما يحتاجون اليه في حياتهم . 


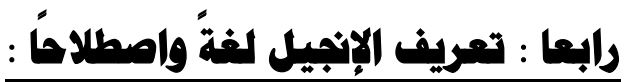

اـ الإنجيل لغة : قيل في تعريف الإنجيل لغة أقوال عدة :القول الأول : النجل ((الولد ، يقال للرجل إذا شتم :

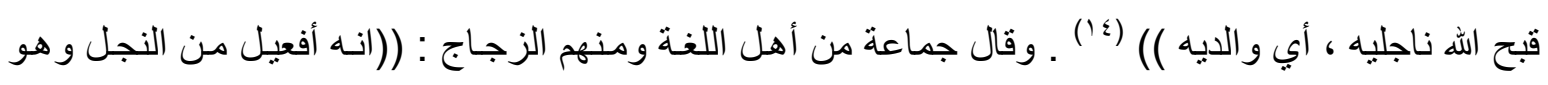

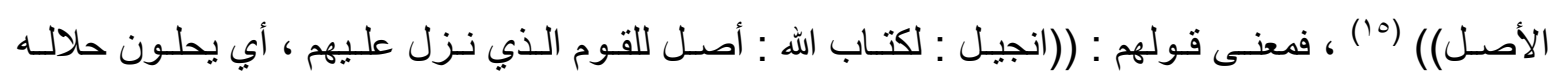

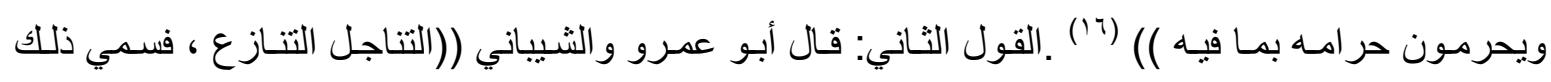

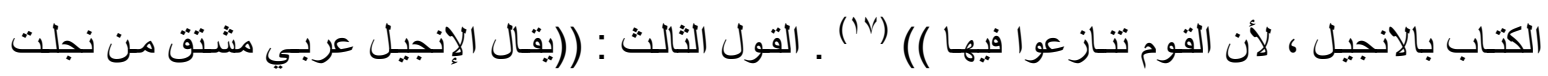

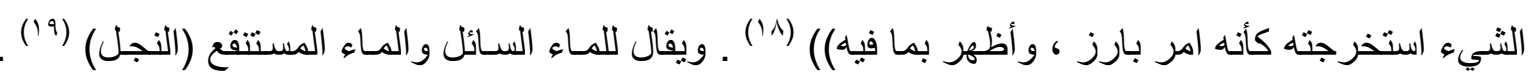

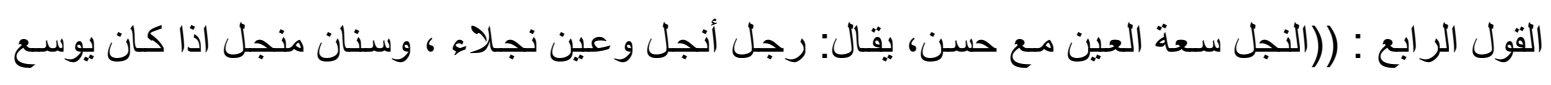

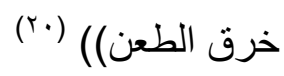
r - الإنجيل اصطلاحًا : ((الإنجيل [ cospels ] كلمة يونانيـة معناهـا [الحلو ان] وهو مـا تعطيه من اتاك ببشرى ، ثم أريد به البشرى عينها ، أما السيد المسيح فقد استعملها بمعنى [بشرى الخلاص] التي حملها إلى الى

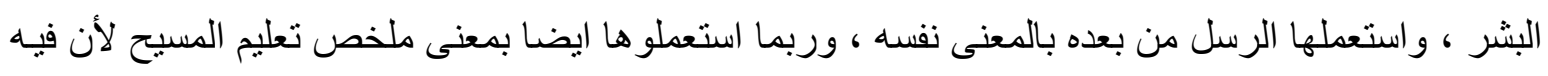

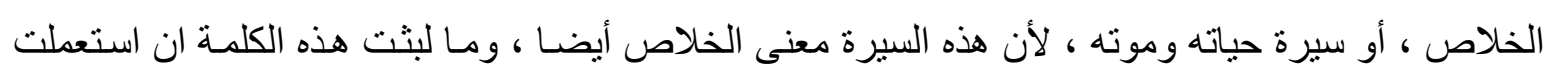

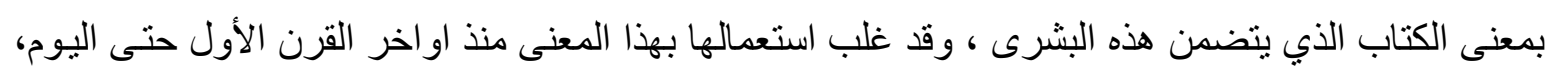

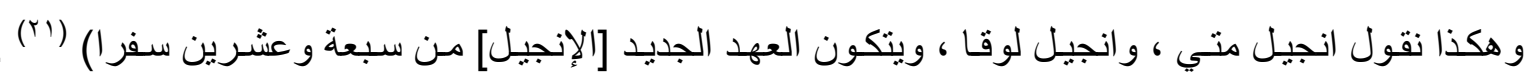

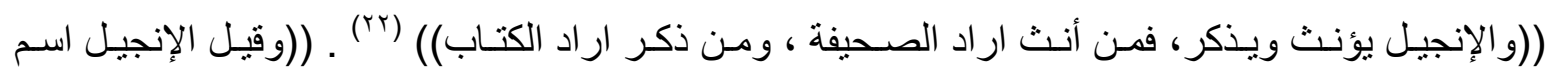

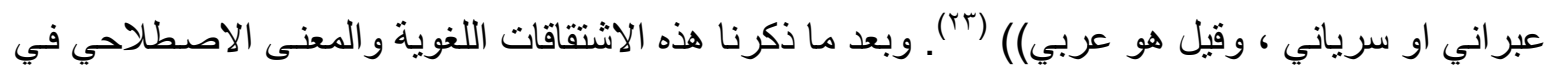

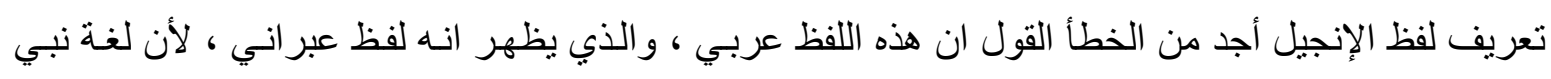
الله عيسى (عليه السلام) هي العبر انية ، وكما ذكرنا في المعنى الاصطلاحي ان معنى الانجيل هي البشرى او

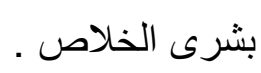

\section{خامساً : تعريف القران لغةُ واصطلامةًا :}

القران لغـة : ((أصل القران مصدر [قر أ] زيد فيه الالف و النون ، كمـا زيد في الطغيـان و الرجحان و الكفران و الخسران ، وان هذا المصدر اريد فيه الوصف )) (عَ)) ـوقيل : ((اراد بالقران القر اعة وهو مصدر

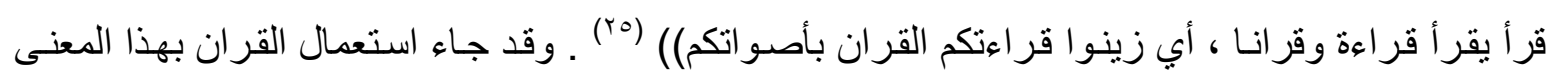

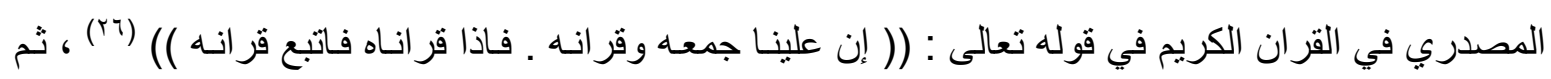

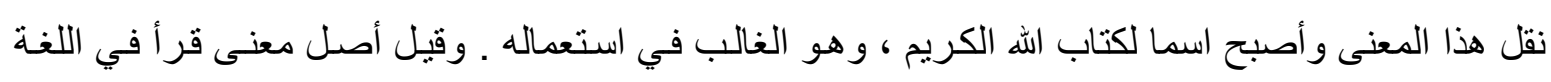

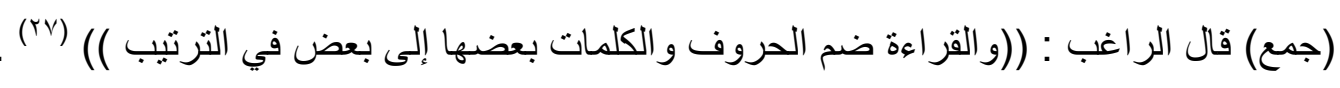

وتأسيسًا على هذا الأصل اللغوي يظهر ان القران وصف من القرء وهو قول جماعة من أهل اللغة:

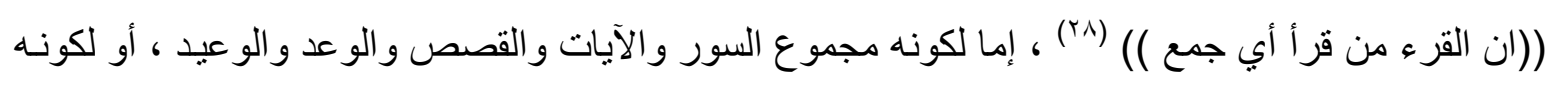

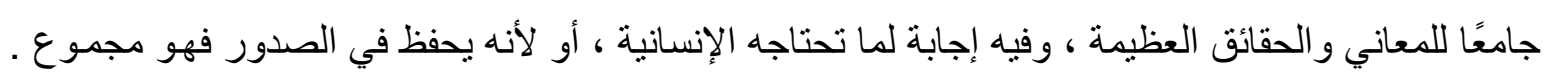

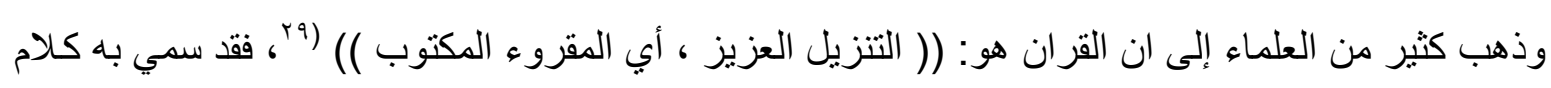


الله تعـالى فاصبح القران بمعنى المقروء ، كالكتاب ، وبمعنى المكتوب. وبـالر غم من اتفاقهم على أن لفظ

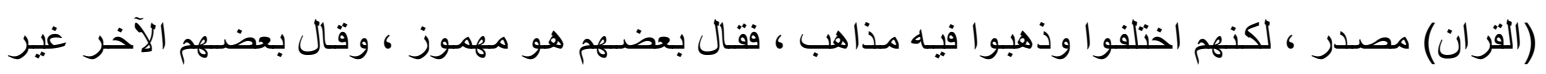

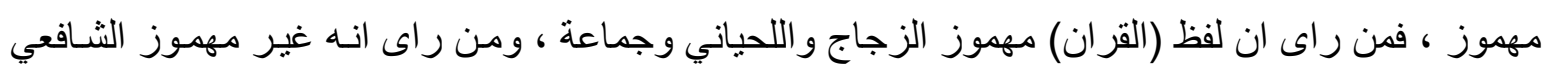

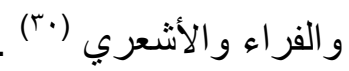

r ـ القران اصطلاحًا : القران الكريم هو قمة التشريع الإسـلامي ، و المرجع المحكم ، فقد عرفه الله سبحانه وتعالى بقوله : (وانه لتنزيل رب العالمين ـ نزل به الروح الأمين . على قلبك لتكون من المنذرين ـ بلسـان

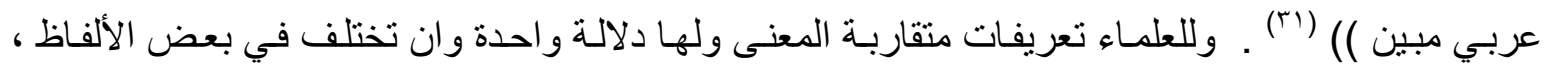

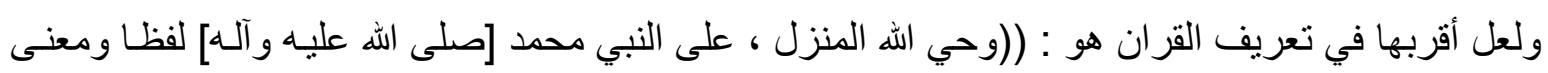

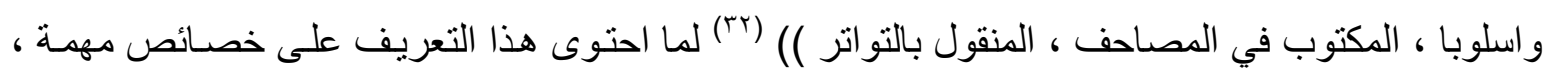
فهو كل ما اوحى به الله سبحانه وتعالى الى رسله و أنبيائه ، أنزله على نبيه محمد (صلى الله عليه و آله) حتى الهى يميزه عن كلام غيره من الإنس والجن والملائكة ، و هو مقيد بنزوله على النبي (صلى الله عليه و آله) بحيث يخرج ما انزل على بقية الأنبياء (عليهم السلام) وميزه عن غيره من كلام رسول الله (صلى الله عليه وآلـه)

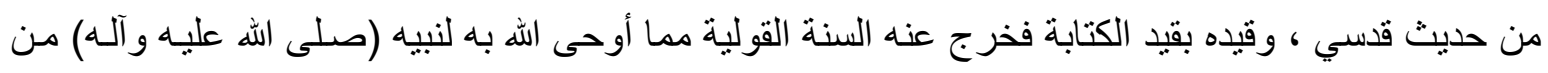
الأحكام وأداها رسول اله (صلى الله عليه و آله) بأسلوبه قولا ، وقيده بالتو اتر ليخرج اخبار الآحاد وهي التي لهي

تخص القراءات الثاذة .

\section{المبمث الأول : هياة إبراهيم (عليه السلام) في منظور الكتب السماوية}

للحديث عن نبي اله إبر اهيم (عليه السلام) يحتاج إلى دراسة حياته باعتباره أبو الأنبياء ومن نسله نبينـا محمد (صلى الله عليه وآله) و أثنبه الناس به ، وهو إمـام أهل التقى والرمز الإيمـاني والأسوة الحسنة للمتقين

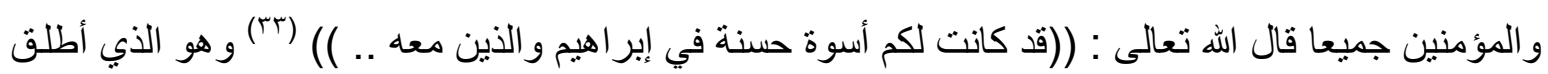

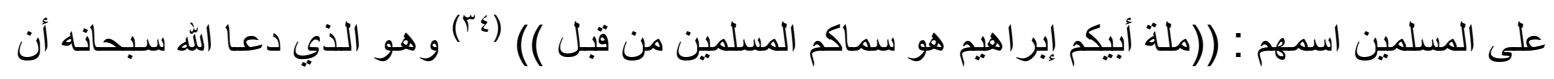

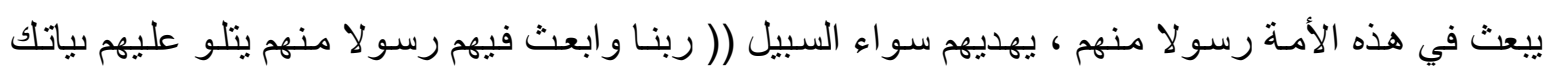

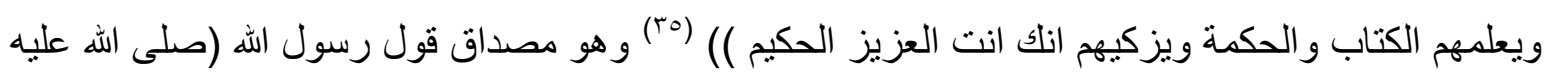

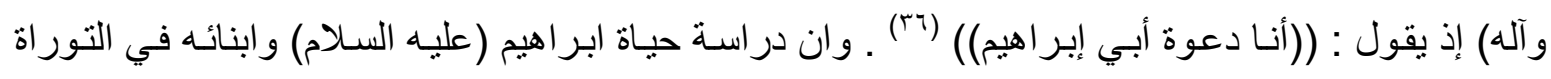

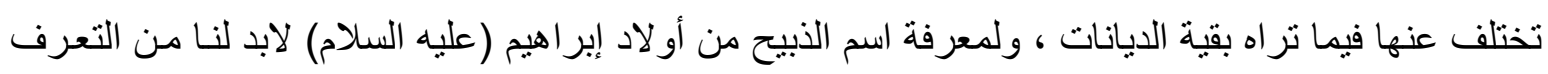

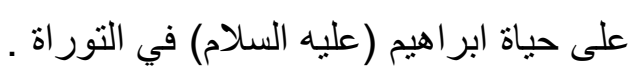

\section{المطاب الأول : هياة إبراهيم (عليه السلام) في التوراة :}

تروي التور اة مولد نبي الله ابر اهيم (عليه السـلام) وتذكر اسمه و اسم ابيهه واخوتـه ، وانهـ كـان يدعى (ابر ام بن تار ح) حتى بلغ عمره التاسع والتسعين ، ثم تغير اسمه واصبح (إبر اهيم) فقد ذكر في سفر التكوين:

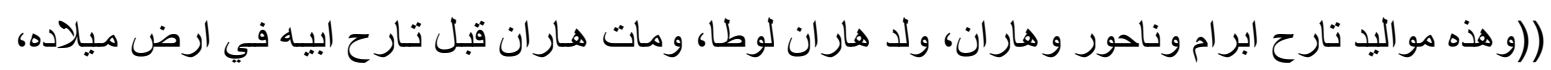

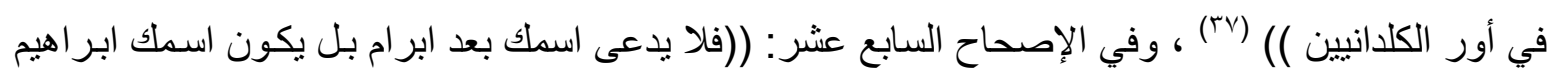

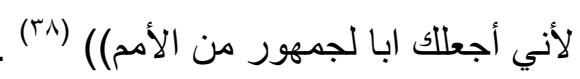


فالخليل إبر اهيم (عليه السـلام) هو الذي تدعي اليهود انهم اليسه ينتسبون ، كمـا جـاءت فيهه التور اة :

(وقال إبر اهيم لله ليت إسماعيل يعيش أمامك ، فقال الله بل سـارة امر اتك تلـ للك ابنا وتدعو اسمه اسحق ،

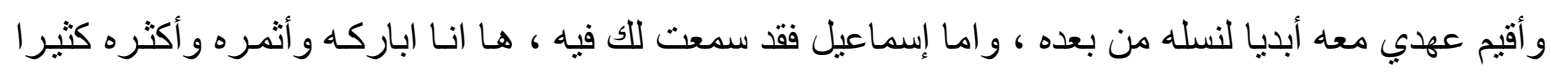
جدا ، اثني عشر رئيسا يلا واجعله امة كبيرة ، لكن عهدي أقيمه مع إسحق الذي تلده سـارة في هذا الوقت في

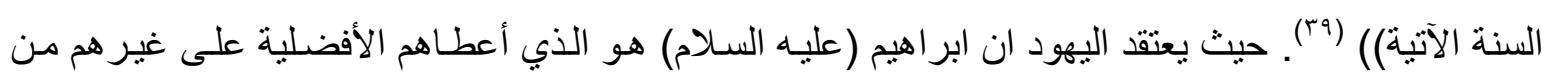
ذريته، فقد ذكر في التوراة: ((فقبح الكلام جدا في عينـي إبر اهيم لسبب ابنهه ، فقال اله لإبر اهيم لا يقبح في الهي

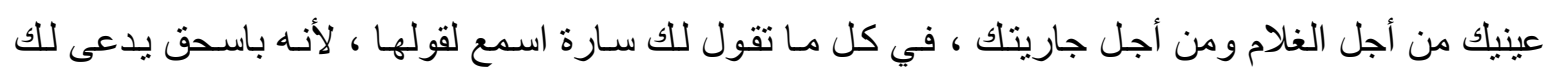

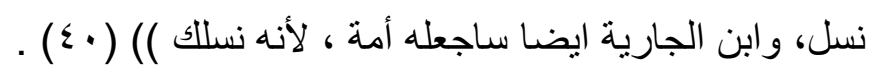

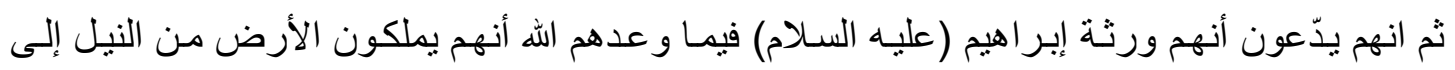

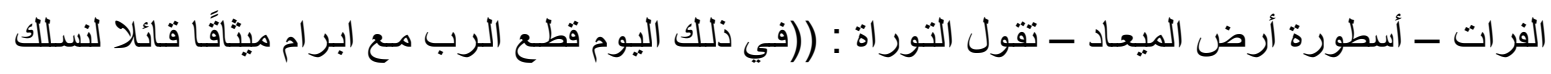
اعط هذه الأرض من مهر مصر إلى النهر الكبير نهر الفرات)) ( (ع) . ويرى اليهود أن نبي الله إبراهيم (عليه السلام) هو الذي أُمِرَ بذبح جدهم إسحق (عليه السلام) كما تذكر التور اة : ((فأخذ إبر اهيم حطب المحرقة ووضعه على إسحق ابنه و أخذ بيده النار و السكين فذهب كلاهما ))

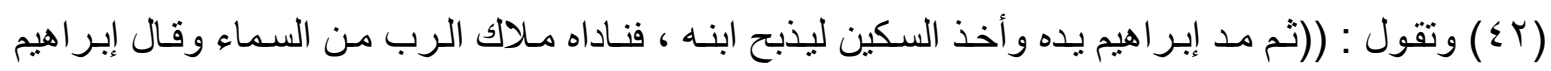

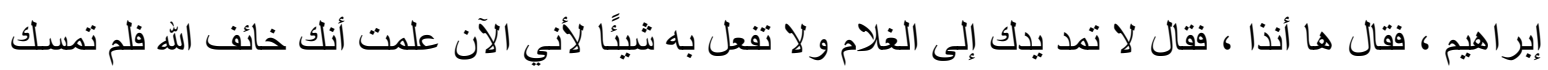

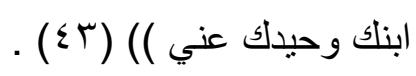

كما وتذكر نصوص التوراة أن قوم إبر اهيم هم من الآراميين : ((قال إبر اهيم لعبده كبير بيته المستولي

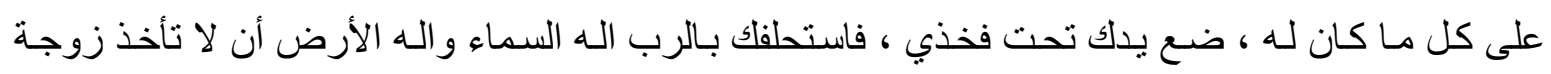

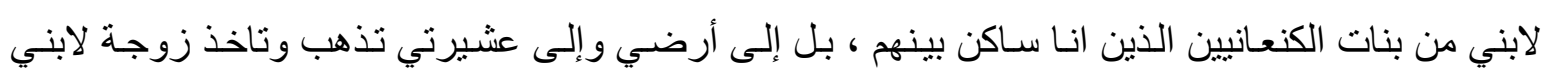
اسحق)) (؟) )، ثم تذكر التور اة : ((ثم أخذ العبد عشرة جمال من جمال مولاه ومضسى وجميع خيرات مو لاه

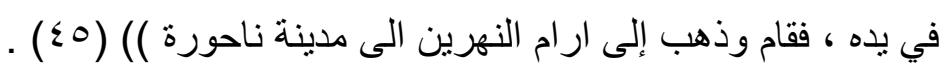

نجد من خـلال مـا تقدم ان التور اة لم تـكر أحوال البر اهيم (عليـه السـلام) مثل تـاريخ حياته ونبوتـهـ

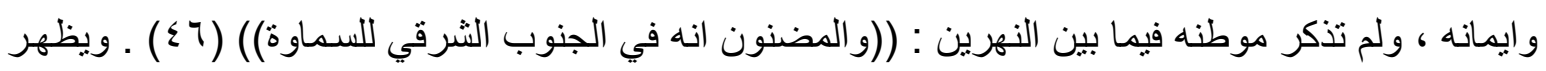

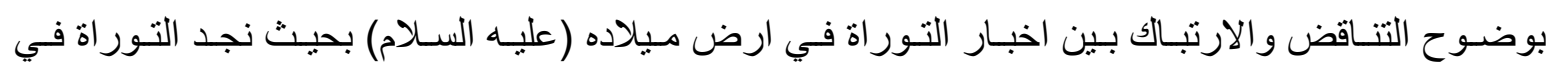

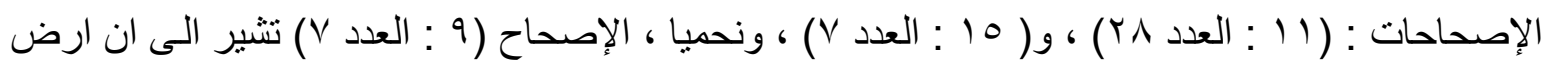
ميلاده (عليه السلام) أور الكلدانيين ، بينما في الإصحاح (؟r : العدد r - ع) نجد أن إبر اهيم (عليه السـلام)

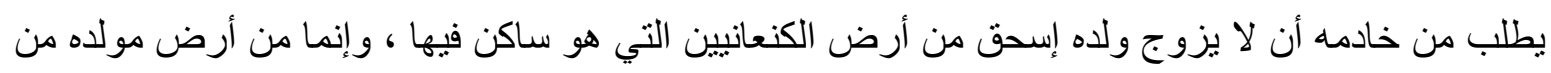
الآر اميين ـ في حين قدمت لنا الدراسات التاريخية وجهني نظر فيما يتصل باور موطن الخليل (عليه السـلام)،

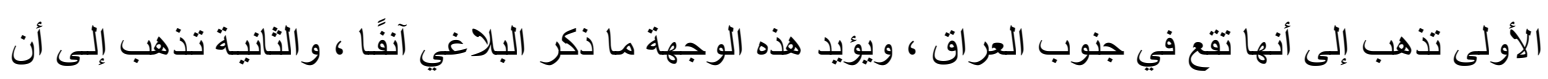
(أور) هذه ليست من بابل ورلا تقع على الخليج العربي بل هي من إقليم العراق الأعلى في منطقة الجزيرة، بين

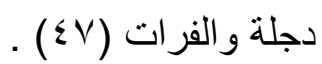


حيث ان اليهود كانوا ينكرون القيامة بعد الموت يقول العقاد: ((ففي عصر الميلاد كانت طائفة كبيرة من اليهود و هي طائفة الصدوقيين تتكر القيامة بعد الموت ، و لا ترى في الكتب الخمسـة دليلًا واضحًا عليها ،

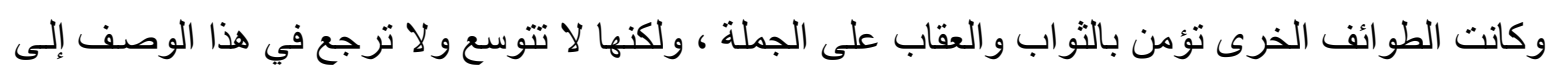

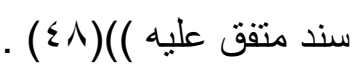

\section{المطاب الثاني : حياة إبراهيم (عليه السلام) في الإنهيل :}

يتفق النصـارى مـع اليهود في اسم الذبيح ، وتذهب انـاجيلهم الأربع ومـا يلحق بها من أقوال الرسل و الحواريين وهو المسمى بالعهد الجديد ، حيث جاء في الرسالة الى العبرانيين : ((بالإيمان قدم إبراهيم إسحق

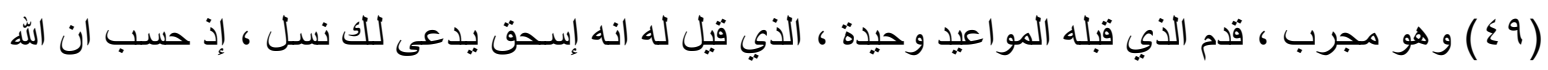

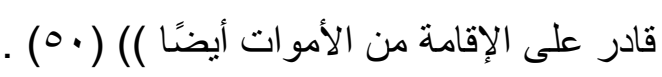

وبهذا فان المسيحية قد جاءت بوصفٍ آخر للعالم لم يكن معروفًا في كتب الديانـة اليهوديـة ، و عليه فقد انتهت بالنسبة لهم إثكالية التوفيق بين ذبح إسحق وحفاظه على النسل للأجيال القادمـة على اعتبار : ((ان الله

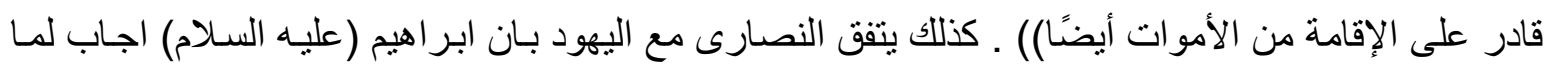

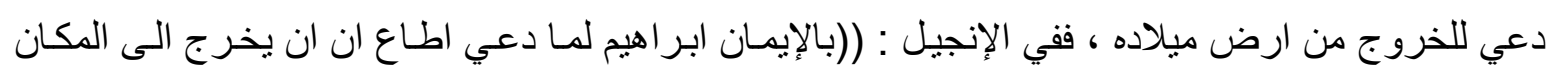

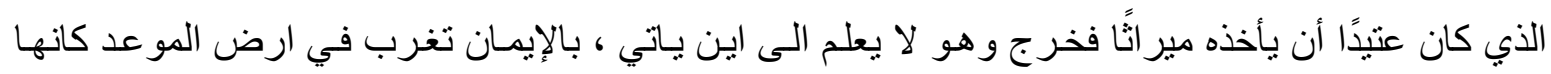

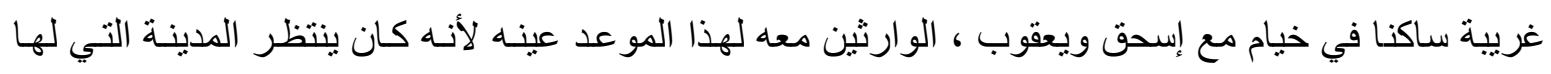

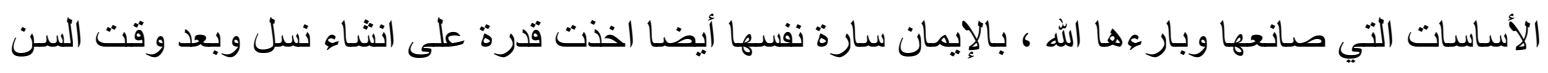
ولدت اذ حسبت الذي و عده صادقا ، لذلك ولد ايضـا من واحد وذلك من ممـات مثنل نجوم السماء في الكثرة

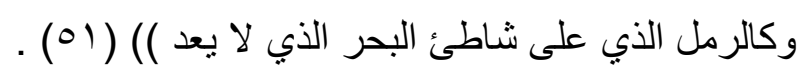

ويظهر لنـا أن الأناجيل لم تضف شيئا جديدا على سيرة ابر اهيم (عليـه السـلام) المذكورة في سفر

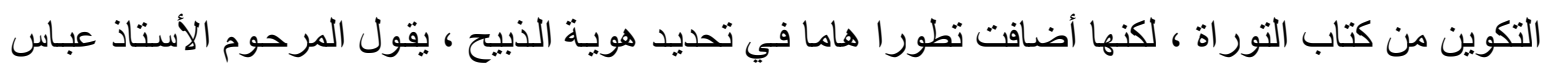
العقاد : ((يبدو هذا التطور الهام في مسائل ثنلاث من كبريات المسائل الدينية ، وهي مسالة الحياة بعد الموت ،

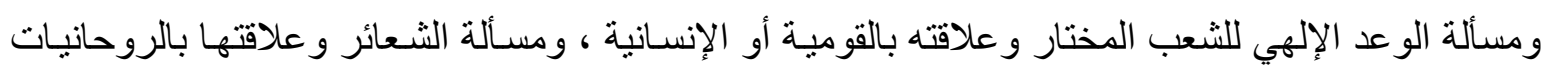

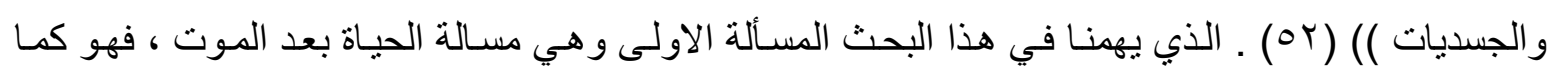
تلاحظ حلٌّ ارتضته المسيحية للتخلص من قضـة ذبـح إسحاق ، حيث انه بشر أن يخرج منـه الثـعب المختار طبقا لخبر التوراة : ((بإسحق يدعى للك نسل)) (rهم) .

فكيف يمكن ان يوفق بين امر ابر اهيم (عليه السلام) ذبح إسحاق (عليه السلام) وهو قد وعد بـان يكون

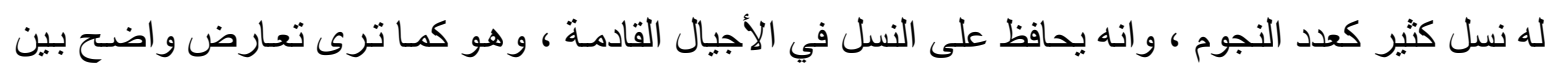
كون ابر اهيم يذبح ابنه الصغير وبنفس الوقت بشر بانه سيكون منه الثـعب المختار ، وهو تعـارض و واضـح ،

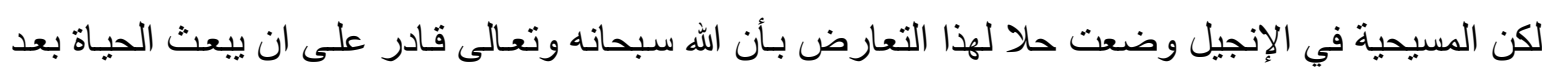
الممات ، و عليه انتهت إنكالية إسحاق (عليه السلام) بانه الذبيح ومنه النسل والأنبياء . 


\section{المطلب الثالث : هياة إيراهيم (عليه السلام) في القران الكريم .}

وياتي القران الكريم في ختام الكتب السماوية للاديان الكبرى (اليهودية و المسيحية) ، ويثبت أخبار إبر اهيم (عليه السلام) و لا نعني هنا بأنها أدلة تاريخية تستمد من روايات واخبار ، و إنما نقصد بإير اد أخبار

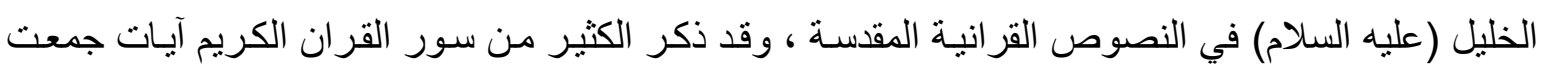

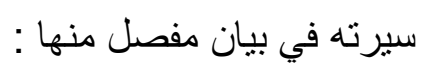

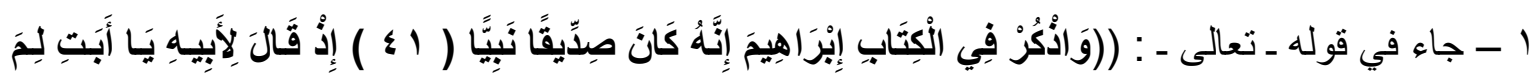

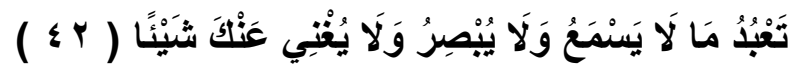

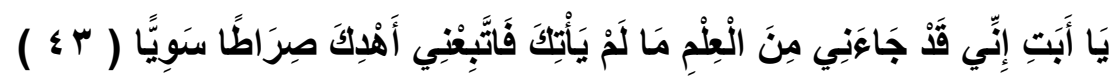

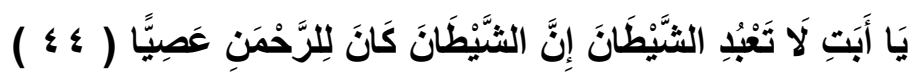

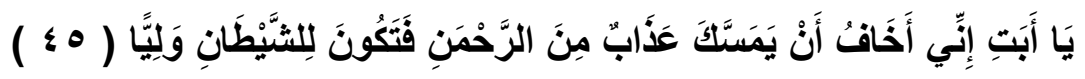

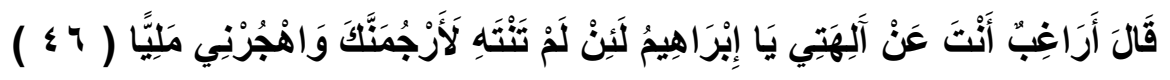

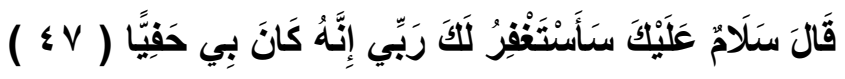

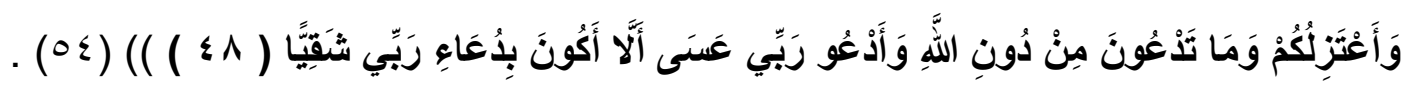

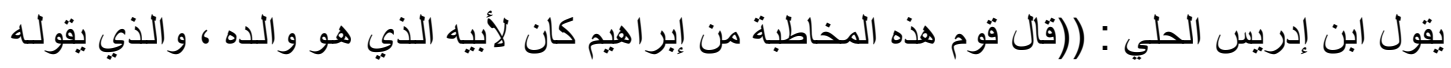

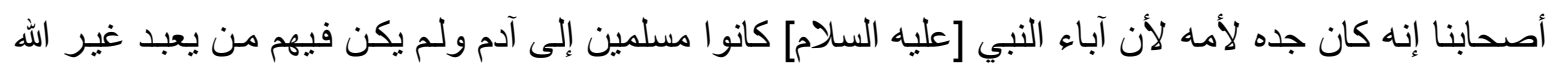

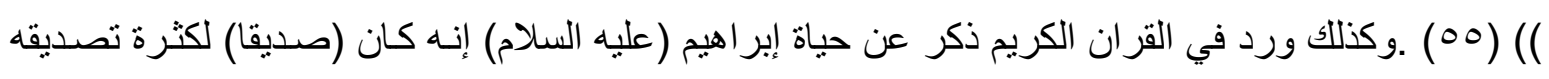

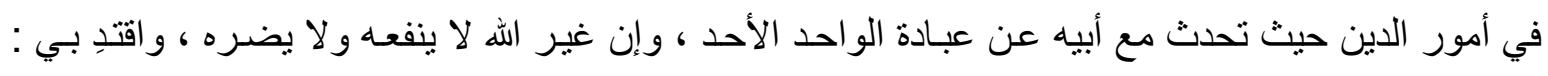

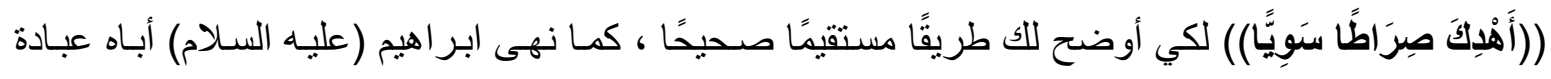

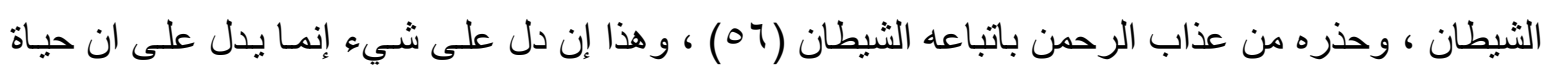

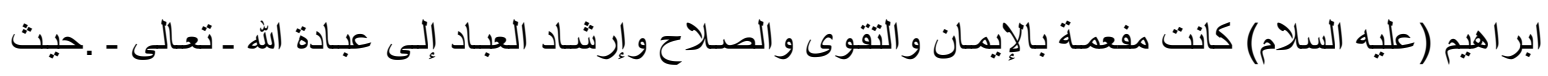

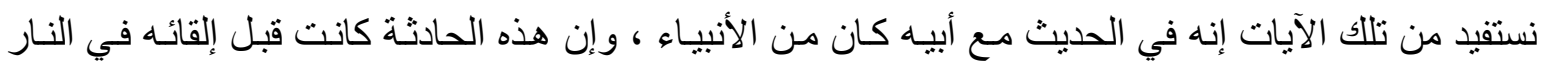

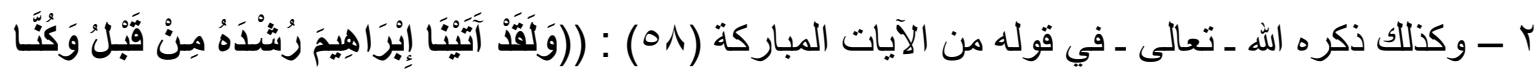

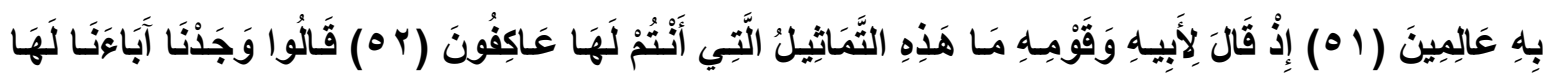

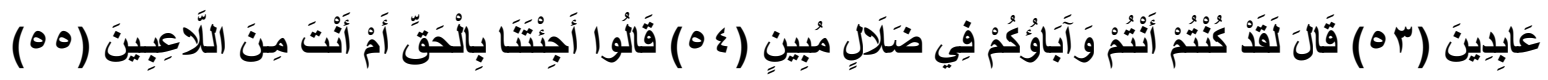

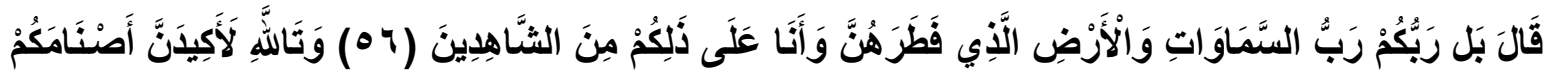

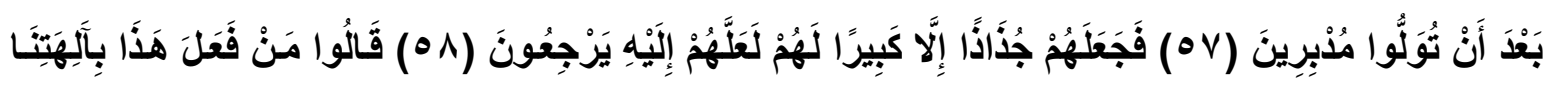

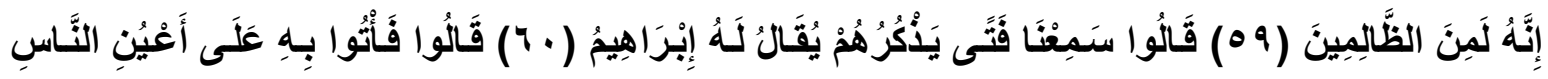

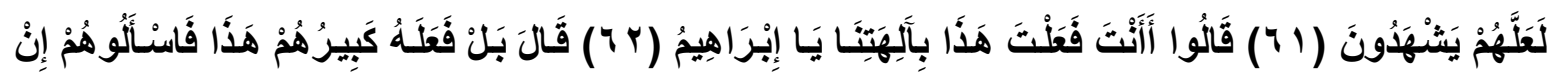




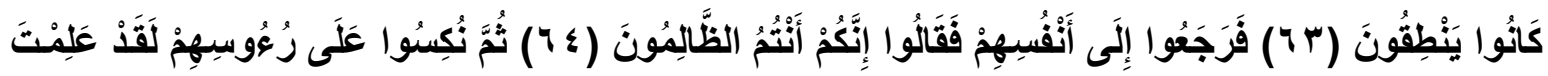

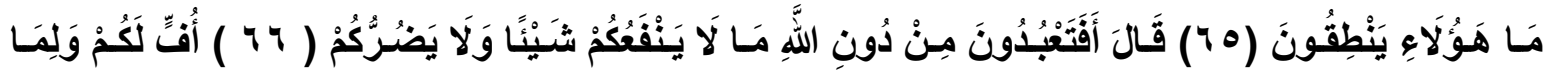

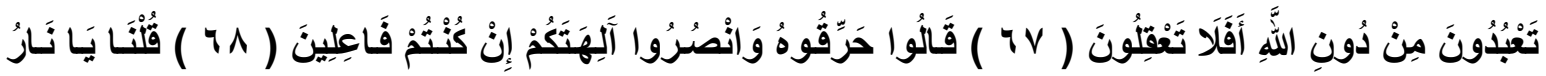

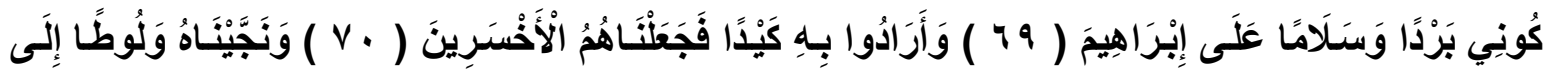

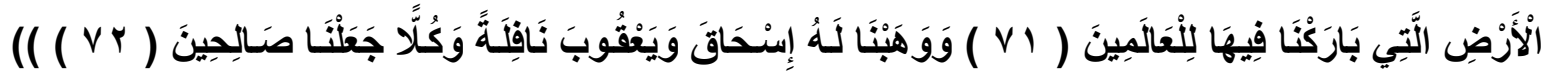

نجد في هذه الآيات سؤالاً موجهًا من إبر اهيم (عليه السلام) إلى قومه كيف أنهم يقسون ويعبدون مـا لا

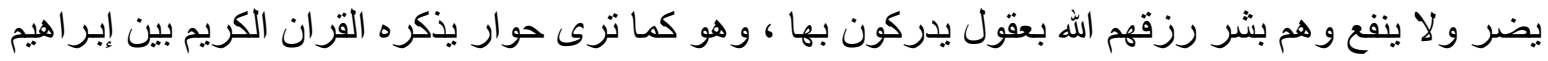

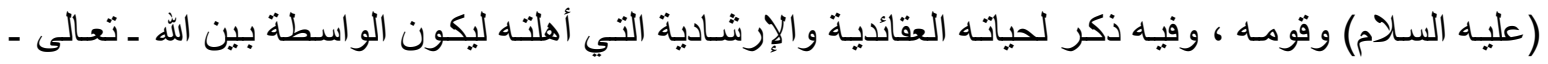

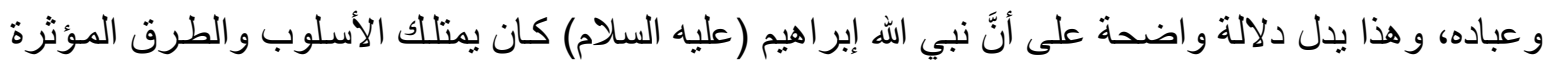

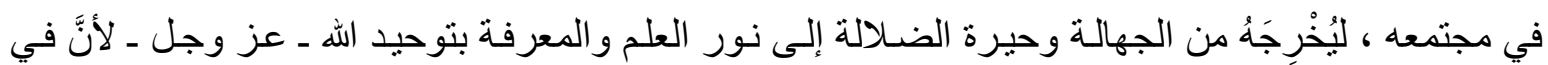
ذللك صلاحهم في أمور دينهم ودنياهم .

\section{المبحث الثاني : إثبات هوية الذبيه في التوراة والإنهيل والقران :}

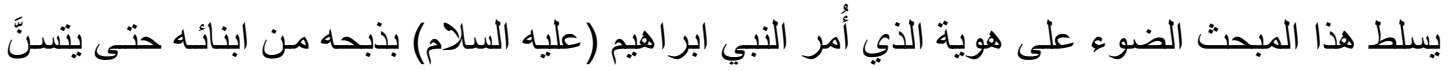

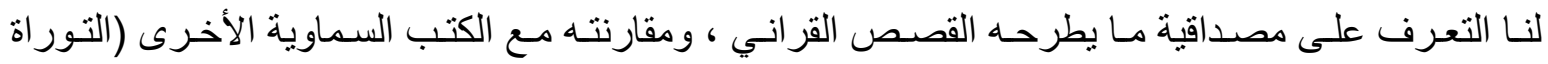
و الإنجيل) في إثبات هويـة الذبيح ، هذا من جانب ، ومن جانب آخر نحاول الرد على إبطال مز اعم أهل

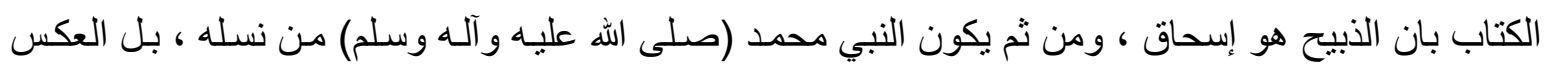

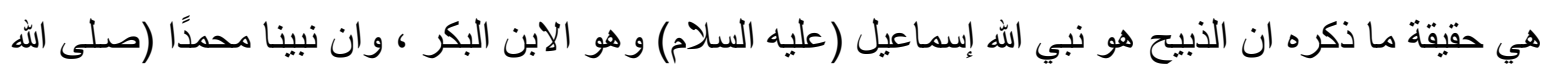
عليه وآله وسلم) هو من نسله .

المطاب الأول : رويا إبراهيم (عليه السلام) في الذبيم:

إن معنى (رؤيا) في كتب المعاجم اللغوية يراد بها الحلم ، عندما تاتي بالالف ، بينما لو جاءت لفظة

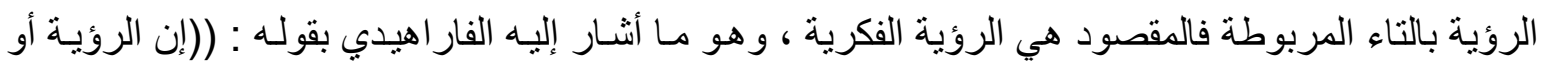
الروية هي النظر أو التفكر في الأمر ولا تجمع الرؤيا)) ( • ج) ـ وقد جاء في القران الكريم ذكر لهذه الرؤيـا

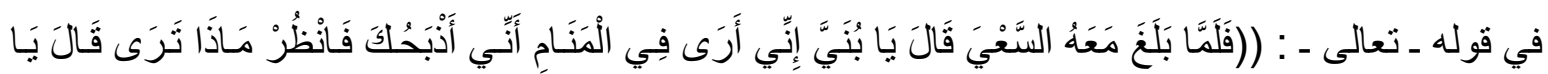

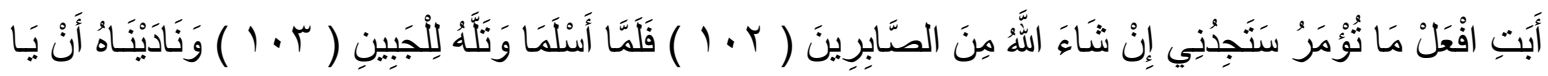

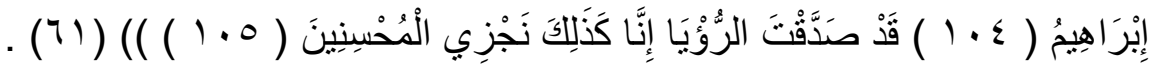
يتضح بشكل جلي في تفسير هذه الايـات الكريمـة ان الله ـ تعـالى ـ اوحى الى نبيـه ابر اهيم (عليه السلام) عن طريق الرؤيا في المنام وهو صورة من صور الوحي التي يوحي بها الله ـ عز وجل ــ إلى انبيائه (عليهم السلام) (rآ) ـ وقد ذكر الثيخ الطوسي ان هذه الرؤيسا في حال اليقظة (بآ) ـ وقيل : ((وكان الله ـ تعالى ـ اوحى الى ابر اهيم في حال اليقظة وتعبده ان يمضي ما يـامره بـه في حال نومـه من حيث ان منامـات 
الانبياء لا تكون الا صحيحة )) (ع 7) . وذهب جمع من المفسرين : (( ان عمر اسماعيل كان [بآ] عامـا

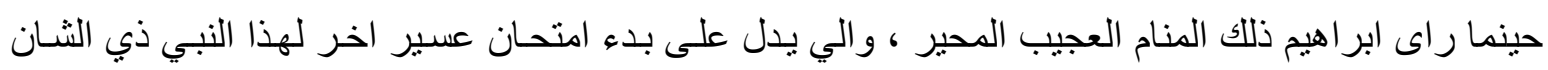

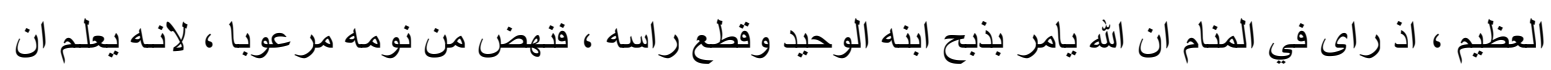

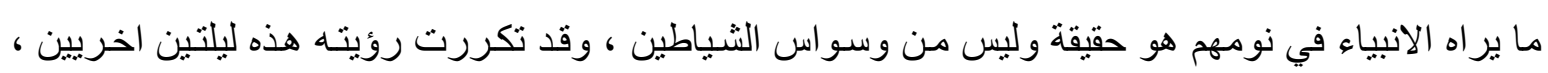

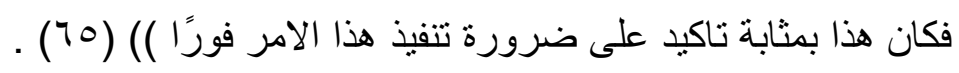
يتضح مما تقدم أن هذه الرؤيـا هي وحي وأمر ، و الأمـر الذي فيـه إلزام بتنفيذ ذبح ولده ، و عليه

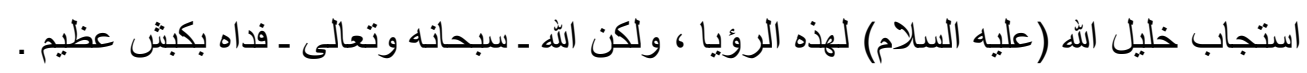

\section{المطلب الثاني : إثبات هوية الذبيه هن التوراة والإنهيل :}

لو تصفحنا التور اة و الإنجيل نجد أن هنالك نصوصًا تشير بشكل واضـح إلى ان الذبيح هو إسماعيل

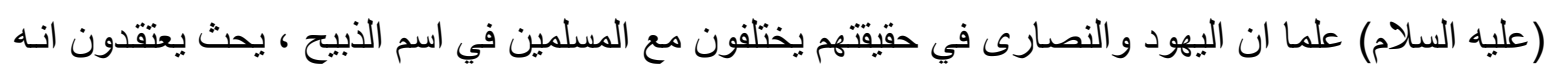

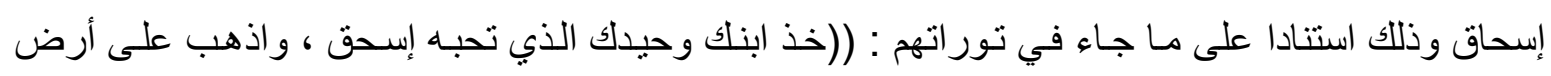

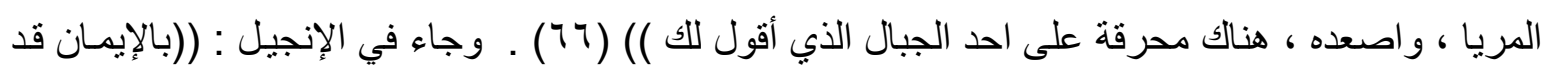
إبر اهيم إسحق و هو مجرب ، قدم الذي قبل المواعيد وحيده ، الذي قيل له بأنه بإسحق يدعى للك نسل )) (TV) بينما نجد في نصوص التوراة والإنجيل مـا يشير ويؤكد أن الذبيح هو إسماعيل (عليه السـلام) :

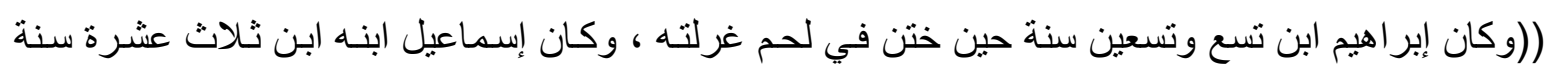

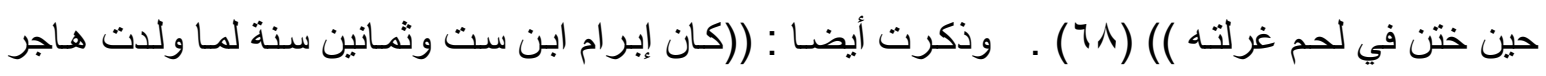

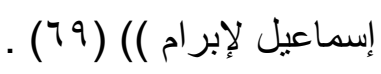

من خلال ما تقدم من نصوص التوراة بان اسماعيل (عليه السـلام) وعمر ابر اهيم ست وثمـانين سنة ،

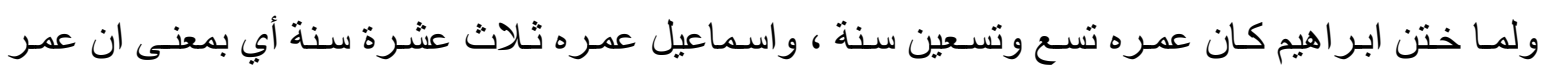

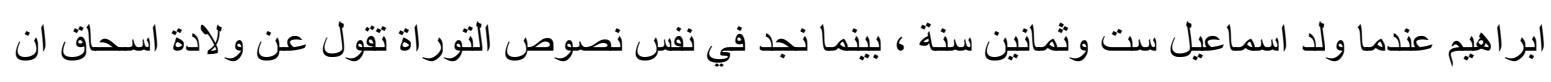

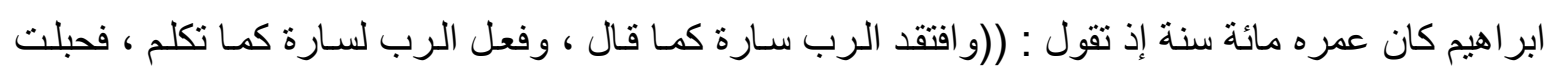

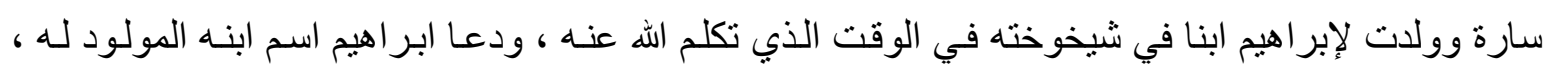

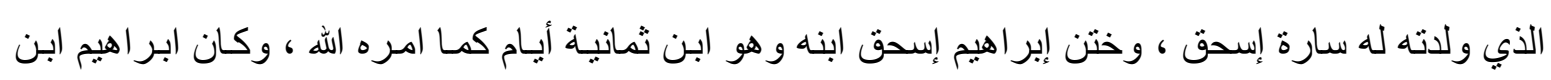

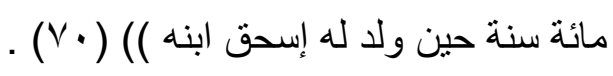
مما تقدم يظهر جليا أن الابن الأكبر والبكر هو اسماعيل (عليه السـلام) فحين ولد كان عمر ابر اهيم

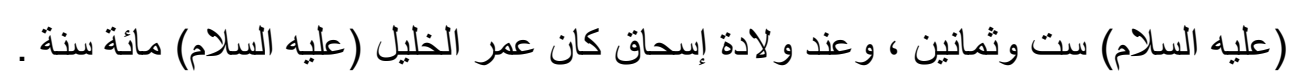

وتضيف التور اة ايضًا بقولهـا : (وقال ابر اهيم لله ليت اسماعيل يعيش امامكك ، فقـال الله بـل سـارة

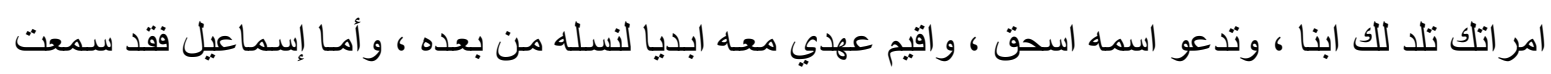

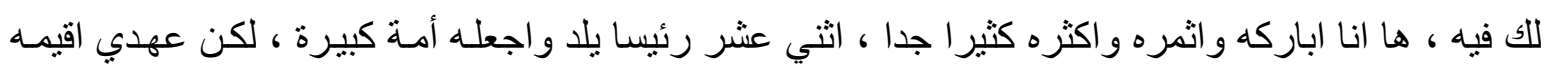

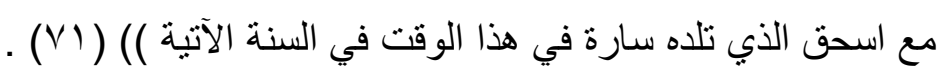


وفي هذا النص أيضًا يظهر لنا أن إبر اهيم (عليه السـلام) كان يخاطب اله ـ تعـالى ـ في إسماعيل ان يعيش أمامه ـ كما تذكر التور اة ـ ان اله ـ سبحانه ـ بشره بان يكون له ولد من سارة اسمه اسحق ويقيم عهده

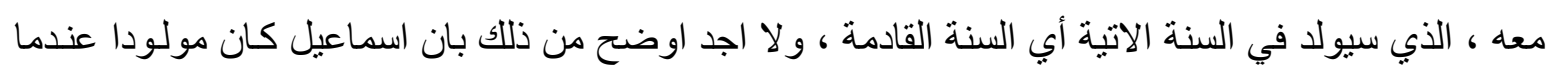

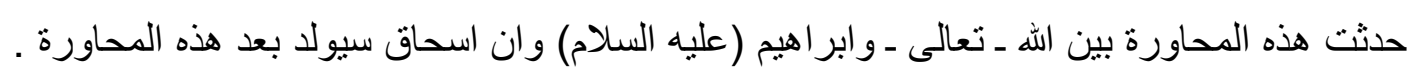
أما النصارى فان ما جاء في ـ الرسالة الى العبر انيين - كان المخرج الذي خرج بـه فقهاء المسيحية كون اسماعيل هو البكر ، فلو كان اسحق هو البكر فكيف يؤمر ابر اهيم بذبح ولده الذي يخرج منسه الثـعب

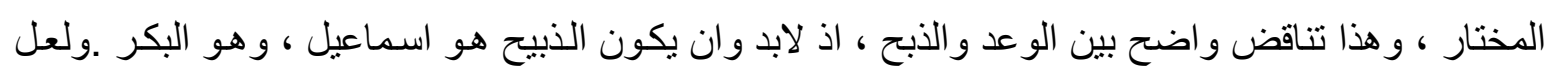

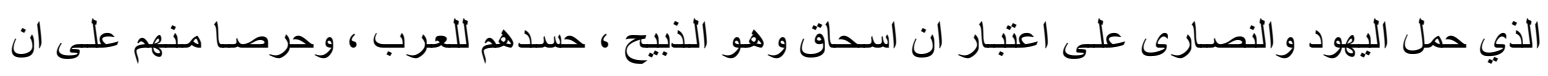
يكون ابو هم هو الذبيح وهو ابو الانبياء (VY) .

\section{المالب الثالث : إثبات هوية الذبيه من القران الكريم :}

ومن أدلة القران الكريم في إثبات أن الذبيح إنما هو إسماعيل (عليه السلام) ، جاء ذكر قصته في سور

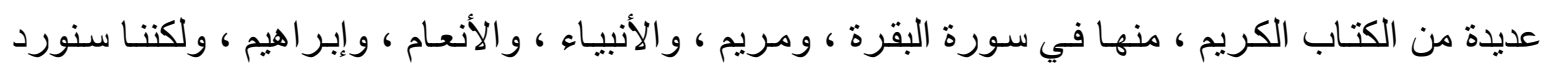
الايات الكريمة في سورة الصـافات على اعتبار أنها وضحت بشكل جلي لا يغيب على المتدبر في القران

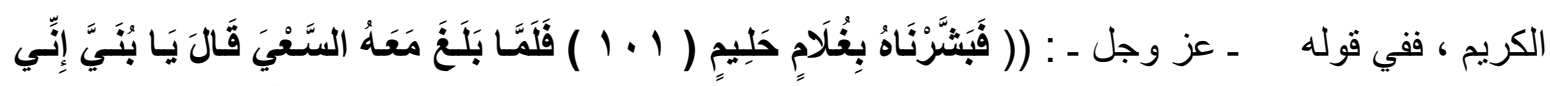

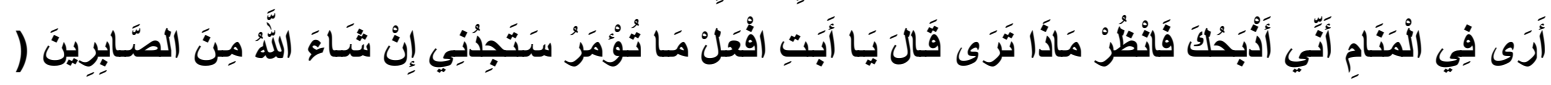

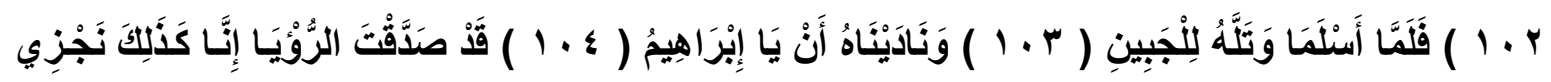

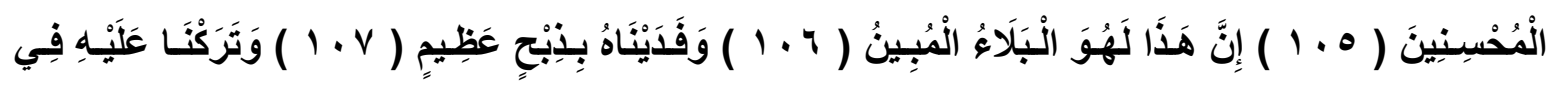

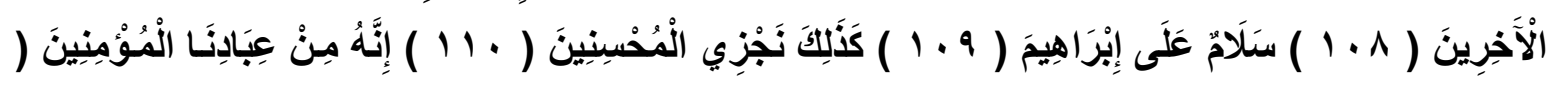

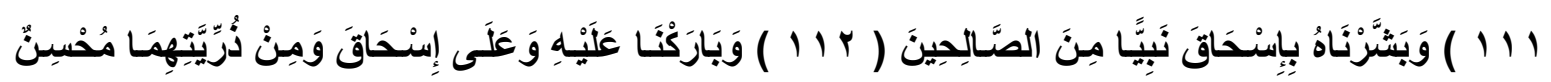

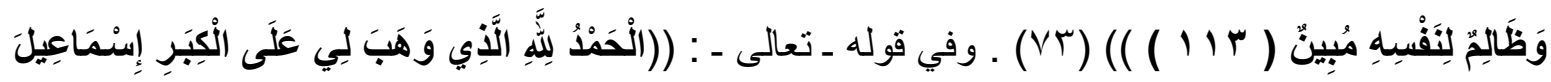

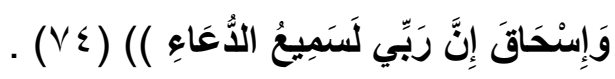

نجد في تلك الايات دليلا واضحا كون الذبيح هو إسماعيل (عليه السـلام) وهو ايضـا الابن الكبر من خلال تسلسل الايات الكريمة ، فقد ذكرت الغلام الحليم الذي بلغ معه السهي ، ثم من بعد ذلك ذكرت اسحاق

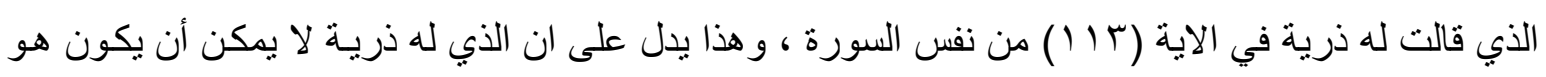

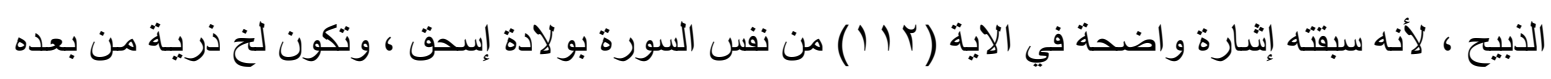

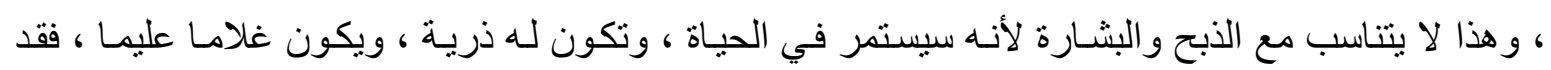

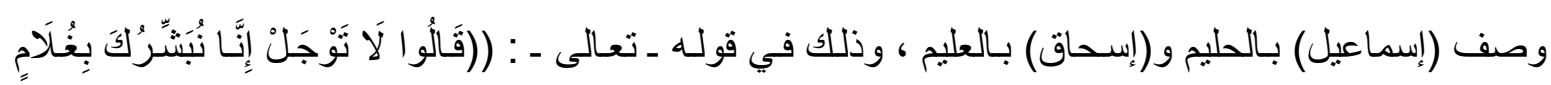

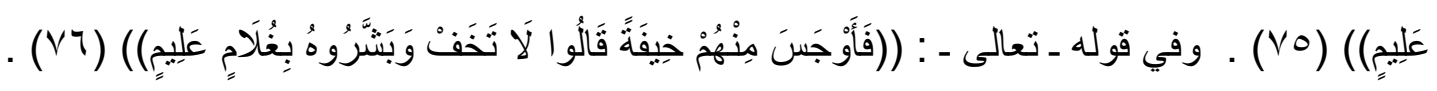
إذا ترتيب التسلسـل القرانسي في ذكر ابنـاء ابـر اهيم (عليـه السـلام) حسـب مـا أوردتـه الايـات القرانيـة الكريمـة ، فقد ذكرت أولًا اسـماعيل وابتـلاءه بالذبح ، ثم بعـد مـا انتهت الايـات القرانبـة مـن ذكر ابـر اهيم

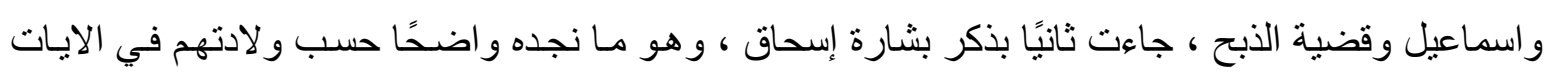




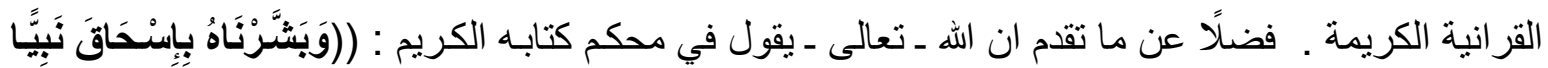

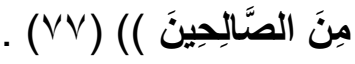

فكيف يأمر الله ـ تعـالى ـ بذبحهـ ، وقد و عده أن يكون نبيًا ، ثم إن البشـارة باسـق إنمـا كانت مقرونـة

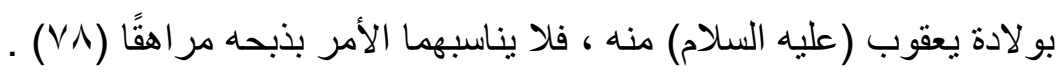
الغاتمة : في الختام التمس البحث بعض النتائج في قضية هوية الذبيح وهي كما يلي : ا - ان نبي الله إبراهيم (عليه السلام) هو عراقي المولد ، عربي الأصل .

r - إن معنى الهويـة لغـة هو مصسطلح ظهر الى الوجـود مـن خـلال الحيـاة السياسية و الثقافيـة ، وامـا في الاصطلاح فكان المعنى هو ان الهوية هي السمة الجوهرية العامة لثقافة من الثقافات . r - ان تعريف الذبح في اللغة يحمل معانٍ عدة ، وقد أوردها البحث بالتفصيل ، أما في الاصطلاح فهو قطع

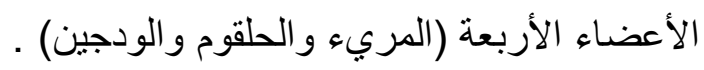
ع - توصل البحث على ان معنى التور اة لغة هو اسم عبر اني وقد تكلف النحاة في اشتقاقها ، وفصلوا القول فيهـا ، أمسا في الاصـلاح فـالتور اة تعنـي الهدايسة والارشـاد ويقصد بهـا الأسفار الخمسـة وهي : (التكوين و الخروج و اللاويين و العدد و التنثية) . ه - ان معنى الانجيل لغة فيه اربعة اقو ال ، وقد ذكر ها البحث في التفصيل ، و المعنى الاصطلاحي له هو مـا تعطيه من حلو اني للذي يأتيك ببشرى . 7 ـ عرف البحث القران الكريم لغة بان القران مصدر قر أ ، أما اصطلاحا فهو وحي الله المنزل على النبي محمد (صلى الله عليه وآله) لفظا ومعنى واسلوبا ، المكتوب في المصاحف ، المنقول بالتو اتر ، وحاول البحث أن يظهر خصائص هذا التعريف . V - استخرج البحث نصوصا من التور اة والانجيل تتحدث عن حياة ابر اهيم عليه السلام ، وقد فصلها البحث 1 - استنطق البحث الايات القر انية وأثبت أخبار ابر اهيم (عليه السـلام) من تلك الايـات بشكل موجز لكثرة تللك الايات في القران الكريم . 9 - سلط البحث الضوء على رؤيا ابر اهيم (عليه السلام) وتناولها بالبحث في معناهـا اللغوي ، و أيدها بآيات من القران الكريم . • 1 - أثبت البحث هوية الذبيح من التوراة والإنجيل بأنه هو نبي الله إسماعيل (عليه السلام) . 11 ـ ـ أثبت البحث هوية الذبيح من سور وايات القران الكريم مستدلا بها على أن الذبيح إنما هو أسماعيل

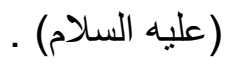
r ا ـ أثبت البحث أن نبينا محمدًا (صلى الله عليه والهه وسلم) من نسل إسماعيل (عليه السـلام) وليس كمـا يظن أهل التوراة والإنجيل . 


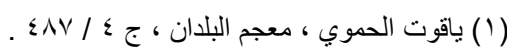

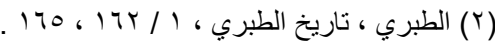

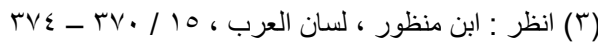

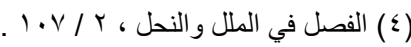

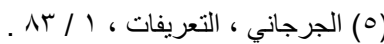

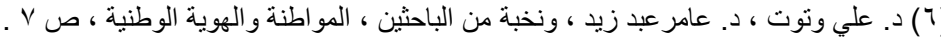

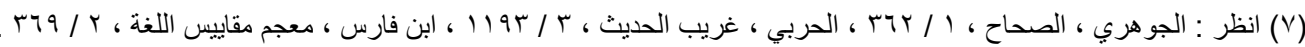

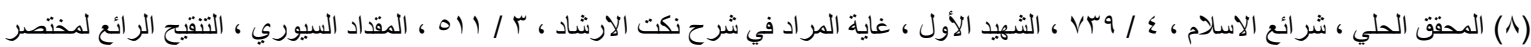

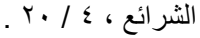

(9) فقد اتفق الامامية و الحنفية و المالكية على اعضـاء القطع ، واختلف الثـافعية و الحنابلة بتحديد اعضـاء القطع ، وهي : الحلقوم و المريء ، ولم يشترطوا

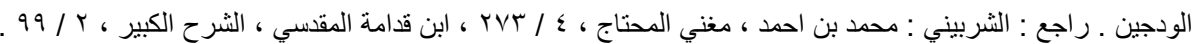

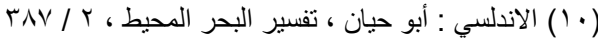

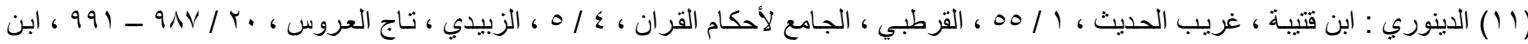

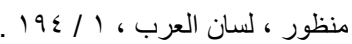

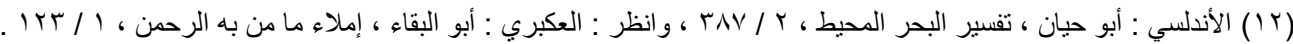

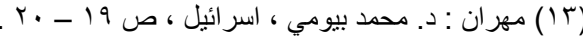

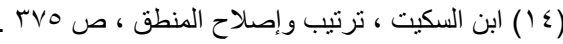

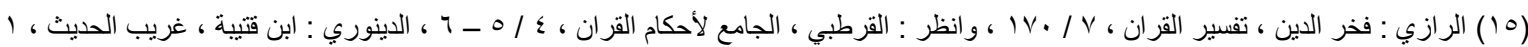

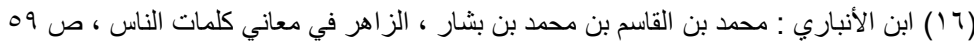

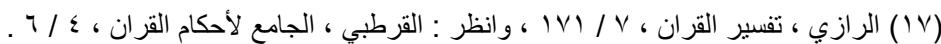

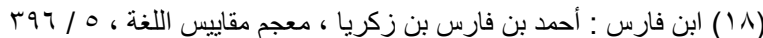

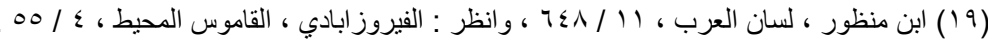

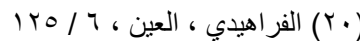

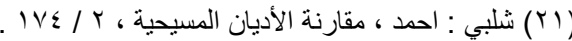

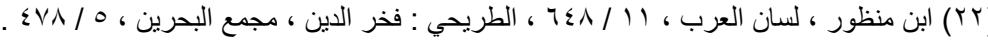

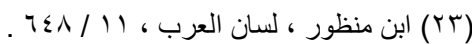

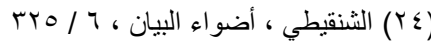

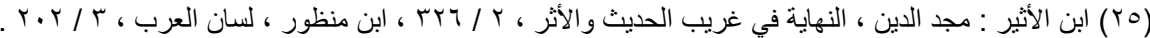

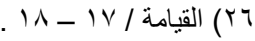

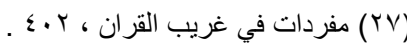

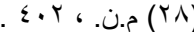

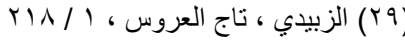

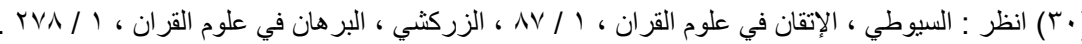

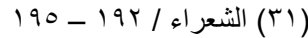

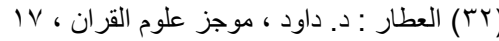

.

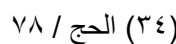

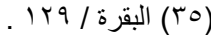

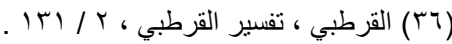

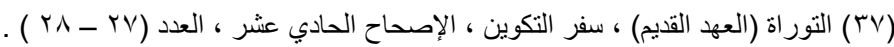

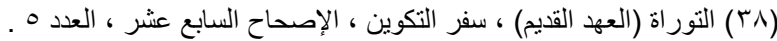

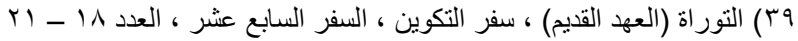

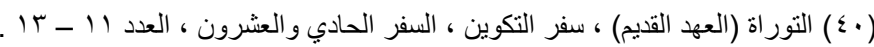

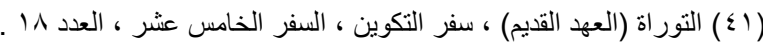




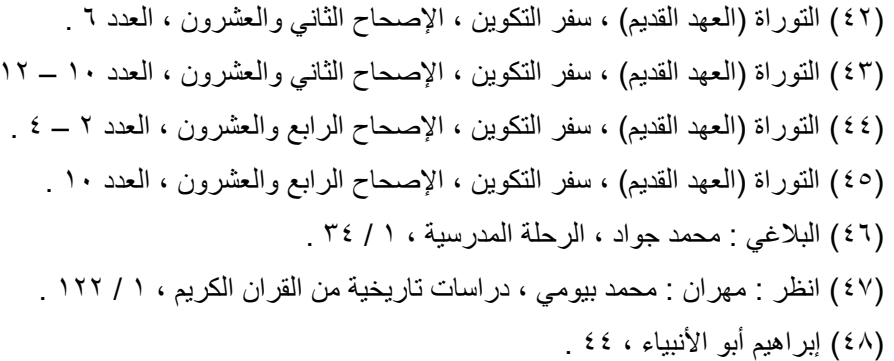

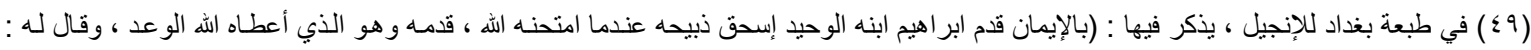

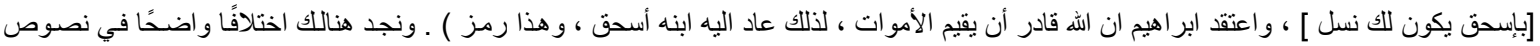

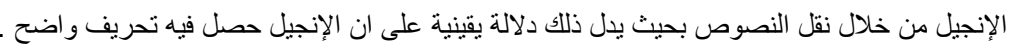

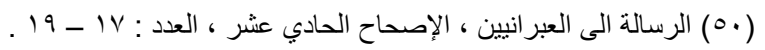

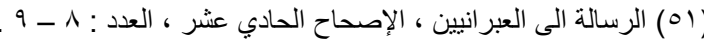

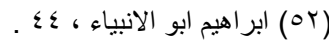

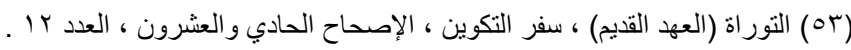

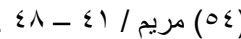

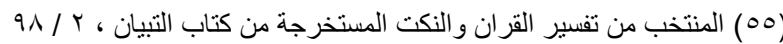

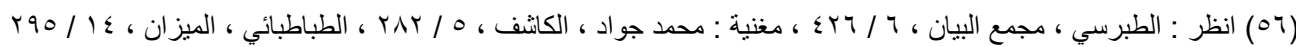

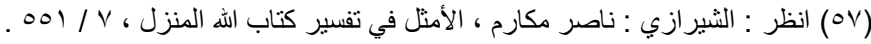

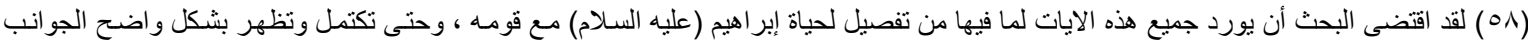
المرتبطة حياته ، لذا اقتضى التنويه . Vr - $01 /$ / الأنبياء (09)

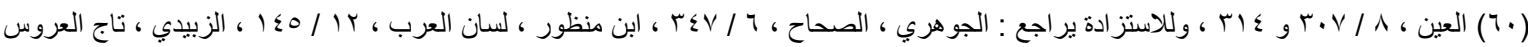
$177-170 / 17$ ،

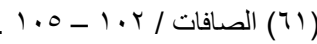

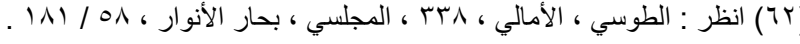

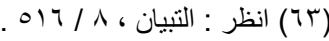

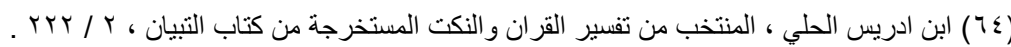

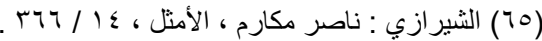

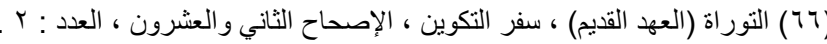

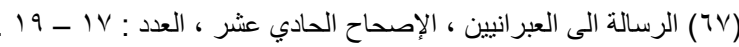

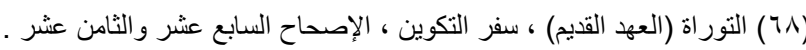

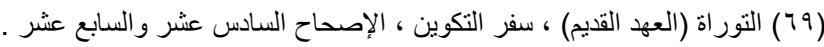

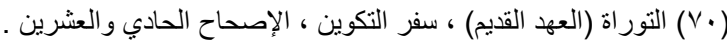

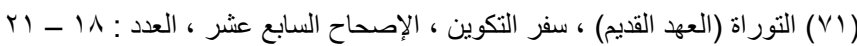

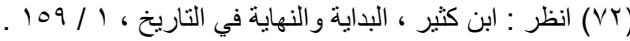

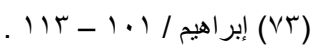

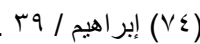

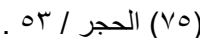

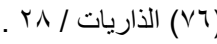

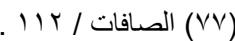
( انظر : الالوسي ، روح المعاني ، بr (VN) 